\title{
Increased activity and expression of histone deacetylase 1 in relation to tumor necrosis factor-alpha in synovial tissue of rheumatoid arthritis
}

\author{
Tomoko Kawabata' ${ }^{1}$ Keiichiro Nishida*2, Koji Takasugi³ , Hiroko Ogawa4, Kenei Sada', Yasutaka Kadota5,
} Junko Inagaki ${ }^{4}$, Satoshi Hirohata4, Yoshifumi Ninomiya ${ }^{4}$ and Hirofumi Makino ${ }^{1}$

\begin{abstract}
Introduction: The purpose of this study was to investigate the profile of histone deacetylase (HDAC) expression in the synovial tissue of rheumatoid arthritis (RA) compared with that of normal control and osteoarthritis $(\mathrm{OA})$, and to examine whether there is a link between HDAC activity and synovial inflammation.

Methods: HDAC activity and histone acetyltransferase (HAT) activity were determined in nuclear extracts of total synovial tissue surgically obtained from normal, OA and RA joints. The level of cytoplasmic tumor necrosis factor a (TNFa) fraction was measured by ELISA. Total RNA of synovial tissue was used for RT-PCR of HDAC1-8. In synovial fibroblasts from RA (RASFs), the effects of TNFa on nuclear HDAC activity and class I HDACs $(1,2,3,8)$ mRNA expressions were examined by quantitative real-time PCR. The protein expression and distribution of class I HDACs were examined by Western blotting.
\end{abstract}

Results: Nuclear HDAC activity was significantly higher in RA than in OA and normal controls and correlated with the amount of cytoplasmic TNFa. The mRNA expression of HDAC1 in RA synovial tissue was higher than in OA and normal controls, and showed positive correlation with TNFa mRNA expression. The protein level of nuclear HDAC1 was higher in RA synovial tissue compared with OA synovial tissue. Stimulation with TNFa significantly increased the nuclear HDAC activity and HDAC1 mRNA expression at 24 hours and HDAC1 protein expression at 48 hours in RASFs.

Conclusions: Our results showed nuclear HDAC activity and expression of HDAC1 were significantly higher in RA than in OA synovial tissues, and they were upregulated by TNFa stimulation in RASFs. These data might provide important clues for the development of specific small molecule HDAC inhibitors.

\section{Introduction}

Rheumatoid arthritis (RA) is an autoimmune disease characterized by chronic inflammation of the synovial tissues in multiple joints that leads to bone and joint destruction. Recent clinical application of biologic agents targeted to inflammatory cytokines including tumor necrosis factor $\alpha$ (TNF $\alpha$ ) or interleukin-1 $\beta$ (IL)- $1 \beta$ dramatically changed the treatment strategy for RA. These molecular therapies of RA are more effective than the

* Correspondence: knishida@md.okayama-u.ac.jp

2 Department of Human Morphology, Okayama University Graduate School of Medicine, Dentistry and Pharmaceutical Sciences, 2-5-1 Shikata-cho, Okayama City, Okayama 700-8558, Japan

Full list of author information is available at the end of the article conventional disease-modifying anti-rheumatic drugs (DMARDs), and can even stop the destructive process in some RA patients [1]. Nevertheless, the etiology of RA inflammation still remains unknown, and there is a demand for developing new therapies with alternative targets.

The characteristic pathology of the RA synovial membrane, including synovial cell proliferation, and persistent recruitment, activation, retention and survival of infiltrated immune cells, might require epigenetic regulation of gene transcription, such as acetylation, methylation and ubiquitination [2]. Among these, histone modification through reversible acetylation is a crucial event in 
gene expression [3]. Histone acetylation is controlled by two enzymes, histone acetyltransferase (HAT) and histone deacetylase (HDAC) [4,5]. Mammalian HDACs are classified into two major classes [6]. Class I HDACs (HDACs 1, 2, 3, 8) are homologues of yeast PRD3 and are found exclusively in the nucleus. Class II HDACs (HDACs 4 to 7 and 9), homologues of yeast Hda1, are found in both the nucleus and the cytoplasm. Gene regulation by HDAC/HAT is complex, because the inhibition of HDAC activity results both in induction and repression of gene expression, depending on the cell types and cell lines [7-11]. Recent studies on the balance of HAT and HDAC activity in human RA synovial tissue indicated that HDAC activity was significantly decreased in RA synovial tissue compared to osteoarthritis (OA) and normal tissues, thus HDAC/HAT might be strongly shifted toward histone hyperacetylation in RA patients [12].

Inhibitors of HDACs, originally developed as anti-cancer agents, exhibit anti-proliferative activity of the cells through multiple mechanisms, such as induction of apoptosis, cell cycle arrest, and promotion of cell differentiation, via modulation of gene expression [13]. It was reported that HDAC inhibitors can also reduce the expression of inflammatory mediators, such as TNF $\alpha$, IL$1 \beta$, IL- 6 , IL-8, transforming growth factor- $\beta$, and nitric oxide that are involved in the pathogenesis of inflammatory diseases [13-18]. We have reported recently that FK228, an inhibitor of class I HDAC shows inhibitory effects on the proliferation of synovial fibroblasts from RA (RASFs) and ameliorates collagen antibody-induced pathology in mice [19]. The inhibition of cell proliferation by FK228 treatment was accompanied by the induction of p16 ${ }^{\mathrm{INK}} 4 \mathrm{a}$ and the up-regulation of $\mathrm{p} 21^{\mathrm{WAF} 1 / \mathrm{Cip} 1}$ expression in RASFs. Moreover, the expression of TNF $\alpha$ and IL-1 $\beta$ was markedly reduced in the synovium of mice treated by
FK228. However, it remains unknown which HDACs are specifically involved in the process of RA inflammation. This information would be necessary for the development of new drugs that would avoid adverse side-effects including haematological toxicity and gastrointestinal symptoms [20,21]. It is unclear why the inhibition of HDAC ameliorates experimentally-induced arthritis $[19,22]$ if HDAC/HAT is shifted toward histone hyperacetylation [12].

Here we investigated the expression profiles of class I and II HDACs (HDAC 1-8) in OA and RA synovial tissues, to identify the candidate HDAC gene in synovial inflammation in RA. We examined HAT and HDAC activities in the total nuclear extracts of synovial tissues from RA patients predominantly treated with conventional DMARDs, and their relationship with the cytoplasmic level of TNF $\alpha$. Our data might provide new leads toward future developments of specific HDAC inhibitors for epigenetic regulation of RA.

\section{Materials and methods \\ Patients and tissue sampling}

We obtained total synovial tissue specimens from 15 RA and 13 OA patients, and 3 normal control patients undergoing orthopedic surgery at Okayama University Hospital, with informed consent from the patients. All RA patients fulfilled the 1987 revised criteria of the American Rheumatism Association [23]. The study protocol is approved by Okayama University Institutional Review Board (accredited ISO9001/2000) and by local ethic committees at respective institute where available. Normal synovial tissues were obtained from amputation surgery for a malignant tumor $(\mathrm{n}=1)$, and ligament reconstruction surgery $(n=2)$. Baseline characteristics of the patients are summarized in Table 1 . Most RA patients were receiving nonsteroidal anti-inflammatory drugs

Table 1: Characteristics of the study subjects

\begin{tabular}{|c|c|c|c|}
\hline & Normal & OA & $\mathbf{R A}$ \\
\hline Age mean (yr) & $19.3 \pm 5.0$ & $75.9 \pm 1.0$ & $65.4 \pm 2.2$ \\
\hline No. of patients & 3 & 13 & 15 \\
\hline $\operatorname{Sex}(F / M)$ & $0 / 3$ & $13 / 0$ & $14 / 1$ \\
\hline Disease duration (yr) & $\mathrm{N} / \mathrm{A}$ & $8.6 \pm 2.2$ & $15.9 \pm 2.7$ \\
\hline $\mathrm{CRP}(\mathrm{mg} / \mathrm{dl})$ & $0.2 \pm 0.1$ & $0.1 \pm 0.4$ & $1.4 \pm 0.4$ \\
\hline \multicolumn{4}{|l|}{ Medication (no of patients) } \\
\hline Oral corticosteroid (mg/dl) & 0 & 0 & $11(4.3 \pm 0.5)$ \\
\hline Methotrexate (mg/day) & 0 & 0 & $9(6.8 \pm 0.8)$ \\
\hline DMARDs others & 0 & 0 & 6 \\
\hline NSAIDs & 0 & 5 & 9 \\
\hline
\end{tabular}

$\mathrm{OA}$, osteoarthritis; RA, rheumatoid arthritis; NA, not applicable; Values are means $\pm \mathrm{SE}$. 
(NSAIDs), oral corticosteroid at $\leq 7.5 \mathrm{mg}$, and DMARDs such as methotrexate (MTX) and sulfasalazine, but not anti-TNFo treatment. RA patients had active disease, as indicated by increased acute-phase reactants (serum Creactive protein $(\mathrm{CRP})$ level $14.3 \pm 4.1 \mathrm{mg} /$ liter). $\mathrm{OA}$ patients and normal controls exhibited no evidence of inflammatory response. Fresh synovial tissues were divided immediately into approximate portions of $333 \mathrm{mg}$ for measurement of HDAC activity, and $30 \mathrm{mg}$ for realtime RT-PCR analysis and stored at $-80^{\circ} \mathrm{C}$.

\section{Isolation and culture of human RASFs}

Fresh synovial tissues were obtained, with written permission from three RA patients during total joint replacement surgery. The tissues were minced and then immediately digested with $0.2 \%$ collagenase (Wako, Osaka, Japan) and DNAase (Sigma-Aldrich St. Louis, MO, USA) at $37^{\circ} \mathrm{C}$, as previously described [24]. Tissue debris was removed with a cell strainer, and the remaining cells were washed twice with medium consisting of Dulbecco's modified Eagle's medium (DMEM; SigmaAldrich) supplemented with 10\% HEPES (Life Technologies, Tokyo, Japan), $100 \mathrm{IU}$ penicillin/ml, and $100 \mathrm{mg}$ of streptomycin/ml (Life Technologies). The resultant single cells were dispensed into the wells of a 24-well microtiter plate (Costar, Cambridge, MA, USA) at a density of $2 \times$ $10^{6}$ cells $/ \mathrm{ml}$ in $2 \mathrm{ml}$ of DMEM supplemented with $10 \%$ fetal bovine serum (FBS), $100 \mathrm{IU}$ of penicillin $/ \mathrm{ml}$, and 100 $\mathrm{mg}$ of streptomycin $/ \mathrm{ml}$. The plates were incubated at $37^{\circ} \mathrm{C}$ in a humidified atmosphere containing $5 \% \mathrm{CO}_{2}$. Synovial cell cultures were divided once weekly until the primary cultures had reached confluence. After the third passage, morphologically homogeneous fibroblast-like cells were obtained. These synovial fibroblast cell lines (Passage 4 to 7 ) were incubated at a density of $1 \times 10^{5}$ cells $/ \mathrm{ml}$ in $10 \% \mathrm{FBS} / \mathrm{DMEM}$ and after $24 \mathrm{~h}$, in $1 \% \mathrm{FBS} /$ DMEM overnight.

\section{Preparation of nuclear and cytoplasmic extracts}

Nuclear and cytoplasmic extracts were obtained from total synovial tissue specimens $(333 \mathrm{mg})$ of patients and cultured RASFs $\left(3.2 \times 10^{6}\right.$ cells), using the Nuclear Extract kit (Active Motif, Carlsbad, CA, USA) according to the manufacturer's instructions. RASFs were incubated with or without $10 \mathrm{ng} / \mathrm{ml}$ of recombinant TNF $\alpha$ (R \& D Systems, Minneapolis, MN, USA) at the indicated time $(0,3,6,12,24 \mathrm{~h})$ and $(0,24,48 \mathrm{~h})$ before extraction. Supernatants were harvested as cytoplasmic fractions. Pellets were resuspended in $100 \mu \mathrm{l}$ (synovial tissue) and $25 \mu \mathrm{l}$ (RASFs) of Complete Lysis Buffer and centrifuged at $14,000 \times g$ for 10 minutes at $4^{\circ} \mathrm{C}$; supernatants were saved as the nuclear fractions. The protein concentration of each sample was measured (Bradford Bio-Rad Protein
Assay kit, Bio Rad, San Diego, CA, USA), with bovine serum albumin used as a standard.

\section{Measurement of HDAC activity}

HDAC activity was measured with a non-isotopic assay that used a fluorescent derivative of epsilon-acetyl lysine (HDAC Fluorescent Activity Assay Kit, Biomol, Plymouth Meeting, PA, USA), according to the manufacturer's instructions. Briefly, $6 \mu \mathrm{g}$ nuclear protein was diluted in assay buffer and incubated at $37^{\circ} \mathrm{C}$ with cell extracts and trichostatin A (TSA), a classic HDAC inhibitor, and then the HDAC reaction was initiated by the addition of Fluorde-Lys substrate. After 10 minutes, Fluor-de-Lys Developer was added, and the mixture was incubated for another 10 minutes at room temperature. Fluorescence was measured using a microplate reader (DS Pharma Biomedical, Suita, Osaka, Japan) with excitation at $380 \mathrm{~nm}$ and emission at $460 \mathrm{~nm}$. The HDAC activity was expressed as arbitrary fluorescence units. The results are expressed as micromolar values of the provided standard per $6 \mu \mathrm{g}$ of protein.

\section{Measurement of HAT activity}

HAT activity was measured using a commercially available, non-radioactive HAT activity assay kit (Active Motif, Co., Ltd, Carlsbad, CA, USA), according to the detailed instructions provided by the manufacturer. Nuclear extracts were prepared from synovial tissues obtained from five OA and five RA patients. Briefly, $3 \mu \mathrm{g}$ nuclear protein was incubated in HAT assay buffer containing $0.5 \mathrm{mM}$ acetyl-CoA and histone $\mathrm{H} 3$ peptide (5.16 $\mu \mathrm{g})$ for 30 minutes at room temperature. The reaction was stopped by adding the stop solution, and after adding the complete developing solution the mixture was incubated for another 15 minutes at room temperature. Fluorescence was measured using a microplate reader (DS Pharma Biomedical) with excitation at $380 \mathrm{~nm}$ and emission at $460 \mathrm{~nm}$. The HAT activity was expressed as arbitrary fluorescence units. The results are expressed as micromolar values of the provided standard per $3 \mu \mathrm{g}$ of protein.

\section{Immunoassays for TNFa}

TNF $\alpha$ plays a central role in regulating pro-inflammatory and anti-inflammatory cytokines in normal, OA and RA synovial tissue. The concentration of TNF $\alpha$ in the cytoplasmic fraction of total synovial tissue was measured by the quantitative sandwich enzyme-linked immunosorbent assay (ELISA) using cytokine-specific capture and biotinylated detection $\mathrm{mAbs}$ and recombinant cytokine proteins (all from BD Biosciences, San Jose, CA, USA) according to the manufacturer's protocol. The detection limit of the kit for TNF $\alpha$ was $7.8 \mathrm{pg} / \mathrm{ml}$. 


\section{Quantitative real-time RT-PCR for HDAC1-8 and TNFa}

Total RNA was extracted from total synovial tissue $30 \mathrm{mg}$ in size with the use of an RNeasy Fibrous Tissue Mini Kit (Quiagen, Valencia, CA, USA) and was extracted from RASFs $(n=3)$ after stimulation by recombinant TNF $\alpha(10$ $\mathrm{ng} / \mathrm{ml})$ at the indicated time $(0,3,6,24 \mathrm{~h})$ using TRIzol according to the instructions of the manufacturer (Invitrogen, Carlsbad, CA, USA). Two micrograms of total RNA was reverse transcribed to complementary DNA (cDNA) with random primers according to the manufacturer's protocol (Toyobo, Osaka, Japan).

Quantitative real-time RT-PCR analysis was performed using a LightCycler Rapid Thermal Cycling system (Roche Diagnostics, Indianapolis, IN, USA), according to a previously reported protocol [25-27]. The PCR mixture consisted of $1 \times$ SYBR Green PCR Master Mix, which includes DNA polymerase, SYBR Green I dye, dNTPs (including dUTP), PCR buffer, 10 pmoles of forward and reverse primers, and cDNA of samples, in a total volume of $20 \mu \mathrm{l}$. Amplification of a housekeeping gene, $\beta$-actin, was used for normalizing the efficiency of cDNA synthesis and the amount of RNA applied. The sequences of the oligonucleotide primers (HDAC1-8) used are shown in Table 2 and TNF $\alpha$ primer (Roche Diagnostics) was used.

\section{Western blotting for class I HDACs}

Nuclear extracts $(20 \mu \mathrm{g}$ of total protein/lane from synovial tissue and $5 \mu \mathrm{g}$ of total protein/lane from RASF) were subjected to SDS-PAGE using a 5 to $12 \%$ gradient

\section{Table 2: Primer pairs for PCR detection}

\begin{tabular}{|c|c|c|}
\hline \multirow[t]{2}{*}{ HDAC1 } & $\mathrm{F}$ & AGACAGCTGTGGCCCTGGATAC \\
\hline & $\mathrm{R}$ & CGGCAGCATTCTAAGGTTCTCAA \\
\hline \multirow[t]{2}{*}{ HDAC2 } & $\mathrm{F}$ & TGCAGTTGCCCTTGATTGTGA \\
\hline & $\mathrm{R}$ & ATCTGGACACCAGGTGCATGAG \\
\hline \multirow[t]{2}{*}{ HDAC3 } & $\mathrm{F}$ & AGAGTGGCCGCTACTACTGTCTGAA \\
\hline & $\mathrm{R}$ & TGGGTTGGTAGAAGTCCACTACCTG \\
\hline \multirow[t]{2}{*}{ HDAC4 } & $\mathrm{F}$ & GAGCAGGAGCTGGAGAAG \\
\hline & $\mathrm{R}$ & AATGCAGTGGTTCAGATTCC \\
\hline \multirow[t]{2}{*}{ HDAC5 } & $\mathrm{F}$ & GTGTCTCGGCTCTGCTCAGTGTAG \\
\hline & $\mathrm{R}$ & TITGCTGCAAGACTGCCTCATC \\
\hline \multirow[t]{2}{*}{ HDAC6 } & $\mathrm{F}$ & GTCTACTGTGGTCGTTACATC \\
\hline & $\mathrm{R}$ & GGCCTGACAGTAGTAACAC \\
\hline \multirow[t]{2}{*}{ HDAC7 } & $\mathrm{F}$ & CGGGTGCACAGTAAATAC \\
\hline & $\mathrm{R}$ & CCAGAGCCTTAGAGATTCATA \\
\hline \multirow[t]{2}{*}{ HDAC8 } & $\mathrm{F}$ & TGACGGAATGTGCAAAGTAGCAA \\
\hline & $\mathrm{R}$ & TCAAATTTCCGTCGCAATCGTA \\
\hline \multirow[t]{2}{*}{$\beta$-actin } & $\mathrm{F}$ & TTCCTGGGCATGGAGTCCT \\
\hline & $\mathrm{R}$ & AGGAGGAGCAATGATCTTGATC \\
\hline
\end{tabular}

gel, and then transferred onto nitrocellulose membranes (Advantech Co., Ltd, Tokyo, Japan). The membranes were blocked with $5 \%$ skim milk and $0.05 \%$ Tween 20 in TBS ( $\mathrm{pH} \mathrm{7.4)} \mathrm{for} 1 \mathrm{~h}$. and were then incubated with primary antibody in $0.05 \%$ Tween 20 in TBS (pH 7.4) overnight at $4^{\circ} \mathrm{C}$ with polyclonal antibodies against HDAC1, 2, 3, 8 (Santa Cruz Biotechnology, Santa Cruz, CA, USA, HDAC1:SC-7872, HDAC2:SC-7899, HDAC3:SC-11417, HDAC8:SC-11405) and lamin A (Abcam Ltd., Cambridge, UK, ab8980). After washing, blots were stained with appropriate horseradish peroxidase-conjugated secondary antibody. Immunoreactive bands were detected by enhanced chemiluminescence (ECL plus solution, Amersham Pharmacia Biotech, Piscataway, NJ, USA). Protein expression level was quantitated by densitometric analysis as previously reported [28]. Briefly, the intensity of the bands were measured by Image J software, Bethesda, MD, USA [29] and lamin A, a nuclear protein, was used for loading controls.

\section{Statistical analysis}

All results are expressed as means \pm SE. Statistical significance of differences between two groups was determined by the Mann-Whitney U test. Other analysis was performed to compare differences among groups by one-way analysis of variance followed by the Bonnferoni correction. A $P$-value of less than 0.05 was considered statistically significant.

\section{Results \\ Measurement of HDAC activity in RA, OA and normal synovial tissues}

Total nuclear HDAC activity (expressed as micromolar values of the deacetylated HDAC substrate standard per 6 $\mu \mathrm{g}$ of protein) in samples of synovial tissue from RA patients $(n=14)$ was $0.96 \pm 0.08 \mu \mathrm{M}$ of the HDAC standard. This level of activity was significantly higher than those from OA ( $=12$, HDAC activity; $0.62 \pm 0.09, P=$ $0.0052)$ and from normal controls $(\mathrm{n}=3$, HDAC activity; $0.50 \pm 0.04, P=0.015$ ) (Figure 1a).

\section{Measurement of HAT activity in RA, OA and normal synovial tissues}

Total nuclear HAT activity was measured in synovial tissues from normal controls $(7.04 \pm 1.78 \mu \mathrm{M}, \mathrm{n}=3)$, from OA $(7.23 \pm 1.35 \mu \mathrm{M}, \mathrm{n}=5)$ and from RA $(6.28 \pm 1.06 \mu \mathrm{M}$, $\mathrm{n}=5$ ) (Figure $1 \mathrm{~b}$ ). There was no significant difference between normal controls, OA and RA synovial tissues (Figure $1 \mathrm{~b}$ ). We examined the ratio of HDAC to HAT activity on the same patients (OA: $n=5, R A: n=5$ ), but failed to show the significant difference in the ratio of HDAC to HAT activity between OA and RA groups. This might be partly due to small data set, but, at least, HDAC/ HAT was not shifted toward histone hyperacetylation. 


\section{Relationship between nuclear HDAC activity and cytoplasmic TNFa levels}

To establish the relationship between nuclear HDAC activity and cytoplasmic TNF $\alpha$ levels directly, we measured TNF $\alpha$ of the cytoplasmic fraction which was obtained by preparing nuclear extracts of OA $(n=12)$ and RA synovial tissues $(n=12)$. The amount of cytoplasmic TNF $\alpha$ tended to correlate with nuclear HDAC activity (OA: correlation coefficient $\mathrm{r}=0.609, P=0.0358, \mathrm{RA}$ : $\mathrm{r}=0.517, P=0.0852$ ) (Figure 2).

\section{Class I, class II HDACs and TNFa mRNA expressions in total synovial tissue}

To investigate the expression profiles of class I and class II HDACs in RA ( $\mathrm{n}=9)$, OA $(\mathrm{n}=8)$ and normal controls ( $\mathrm{n}$ $=3$ ) synovial tissues, mRNA levels of HDAC1 to 8 were evaluated by quantitative real-time PCR. RA synovial tissues expressed high levels of HDAC1 compared to OA $(P$ $=0.018$ ), and normal controls (Figure 3a). HDAC4 mRNA levels were significantly higher in normal controls than in RA $(P=0.016)$. TNF $\alpha$ mRNA expression was measured in RA synovial tissue. The data showed significant positive correlation between TNF $\alpha$ and HDAC1 mRNA in RA synovial tissue $(\mathrm{n}=10)$ (correlation coefficient $\mathrm{r}=$ $0.757, P=0.012$ ) (Figure $3 b$ ).

\section{Nuclear expression of class I HDACs in synovial tissue}

We performed Western blotting for nuclear class I HDACs in synovial tissue. The level of nuclear HDAC1 protein expression was higher in RA synovial tissue compared with OA synovial tissue (Figure 4a). Western blots were quantified by Image J software [29]. The level of expression of HDAC1 by normalizing to the band density of nuclear membrane protein lamin A was significantly higher in RA than OA synovial tissue $(P=0.0495)$ (Figure 4b) (see Additional file 1).

\section{Measurement of HDAC activity, class I HDACs mRNA expressions and nuclear expressions in RASFs after treatment with TNFa}

Treatment by TNF $\alpha$ significantly increased nuclear HDAC activity in RASFs $(\mathrm{n}=3)$ and peaked at $6 \mathrm{~h}(P=$ 0.0001 vs 0 and $24 \mathrm{~h}$ ) (Figure $5 \mathrm{a}$ ), indicating that TNF $\alpha$ stimulation seems to be associated with nuclear HDAC activity in RASFs. Next, the change of mRNA expression in the class I HDACs after TNF $\alpha$ stimulation was analyzed. The expression of HDAC1 in RASFs $(n=3)$ was increased after TNF $\alpha$ treatment; while the expressions of other class I HDACs were not elevated through the time course $(0,3,6,24 \mathrm{~h})$ (Figure $5 \mathrm{~b})$. When the relative mRNA expressions at $24 \mathrm{~h}$ after stimulation were compared among class I HDACs, the increase of mRNA in HDAC1 was significantly greater than that in other class I HDACs $(P=0.02)$. We performed Western blotting for nuclear class I HDACs in RASFs. Western blots were quantified by Image J software. The nuclear HDAC1 protein expression in RASFs $(n=3)$ was elevated compared to other class I HDACs (HDAC2, HDAC3, HDAC8) after TNF $\alpha$ treatment though the time course $(0,24,48 \mathrm{~h})$. The level of protein expressions by normalizing to the band density of nuclear membrane protein lamin A at $48 \mathrm{~h}$ after TNF $\alpha$ treatment tended to increase in HDAC1 $(P=$ 0.0654 ; versus HDAC2, $P=0.049$; versus HDAC3, $P=$ 0.0354; versus HDAC8) (Figure 5c) (see Additional file 2).

\section{Discussion}

Previous reports indicated that HDAC inhibitors exhibit anti-inflammatory properties, and might play a beneficial role in the treatment of inflammatory diseases, such as ulcerative colitis, lupus erythematosus and hepatic injury [14,30-32]. In contrast, HDAC inhibitors have been shown to enhance lung and microglial inflammation, suggesting that HDAC inhibitors might modulate inflammation in a cell type-specific manner. We demonstrated recently that FK228, a specific class I HDAC inhibitor, prevents the in vivo proliferation of RASFs and ameliorates the pathological changes of autoantibody-mediated arthritis in mice [19]. These results strongly suggested that modulation of the transcriptional activity of specific promoters in response to the local release or perturbation of chromatin structure, by treatment with HDAC inhibitors, could effectively prevent the synovial proliferation and joint destruction seen in human RA. It is still not known however, which HDAC was a candidate gene that should be targeted in the process of human RA inflammation.

In this study, we demonstrated that total nuclear HDAC activity is increased in samples of human RA synovial tissues compared to that in samples of OA and normal subjects. Interestingly, our results were the opposite of that reported by Huber et al $[12,33]$. The following factors may lead to the discrepancies between the two studies. First, they obtained the synovial samples during joint replacement surgery of seven RA patients, six OA patients and three control subjects. In RA, three patients received TNF $\alpha$ blockade and all normal samples were obtained via autopsies. As synovial tissue under TNF $\alpha$ blockade would not represent the regular RA inflammation, and HDAC/HAT activity might change after mortality, we excluded the patients receiving TNF $\alpha$ blockade treatment, and all samples were obtained at surgery. Second, they demonstrated lower levels of HDAC1, and HDAC2 protein in RA synovium than in OA by Western blotting of whole cell lysates, with $\alpha$-tubulin as an internal control. Because HDAC1 and HDAC2 are localized mainly at the cell nuclei, we compared the nuclear protein levels of HDACs between RA and OA, with lamin A as an internal control, and showed a significant increase of HDAC1 protein in RA cells. This discrepancy might have 
(a)

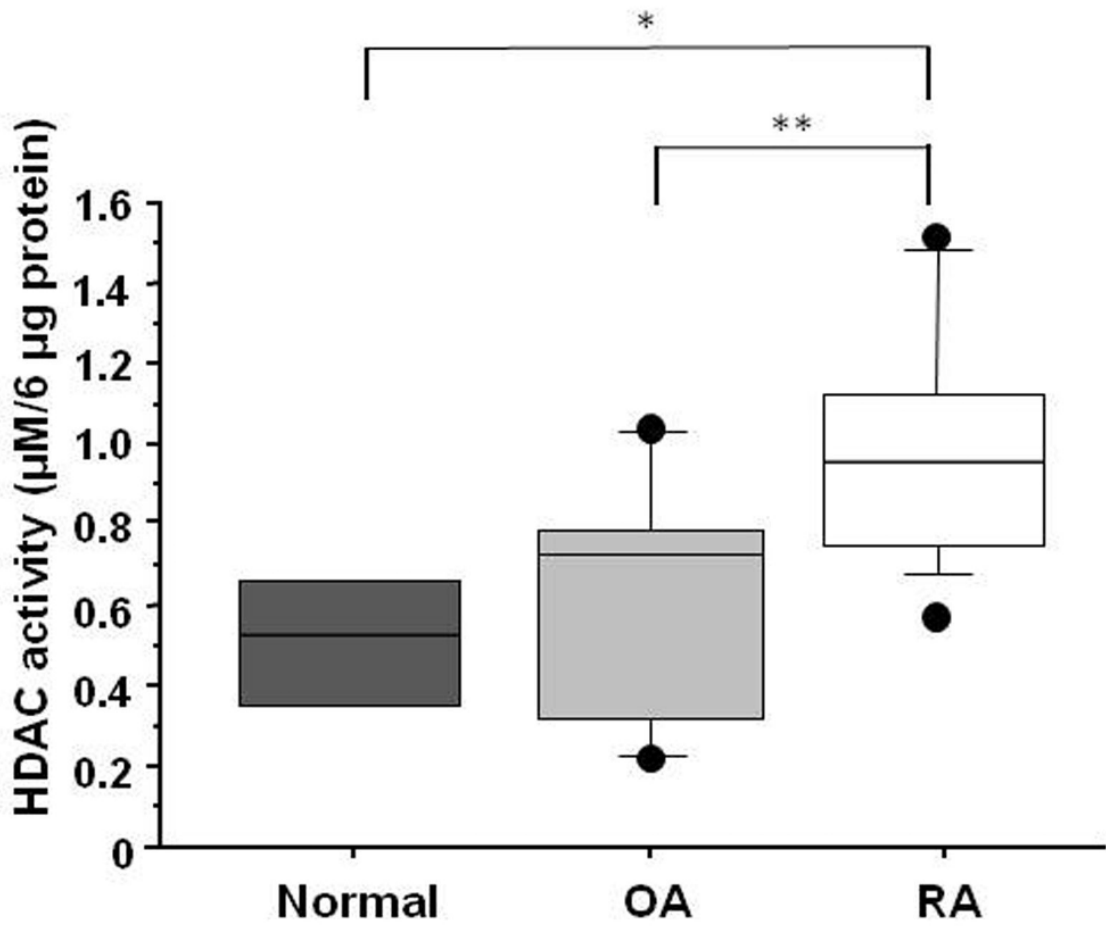

(b)

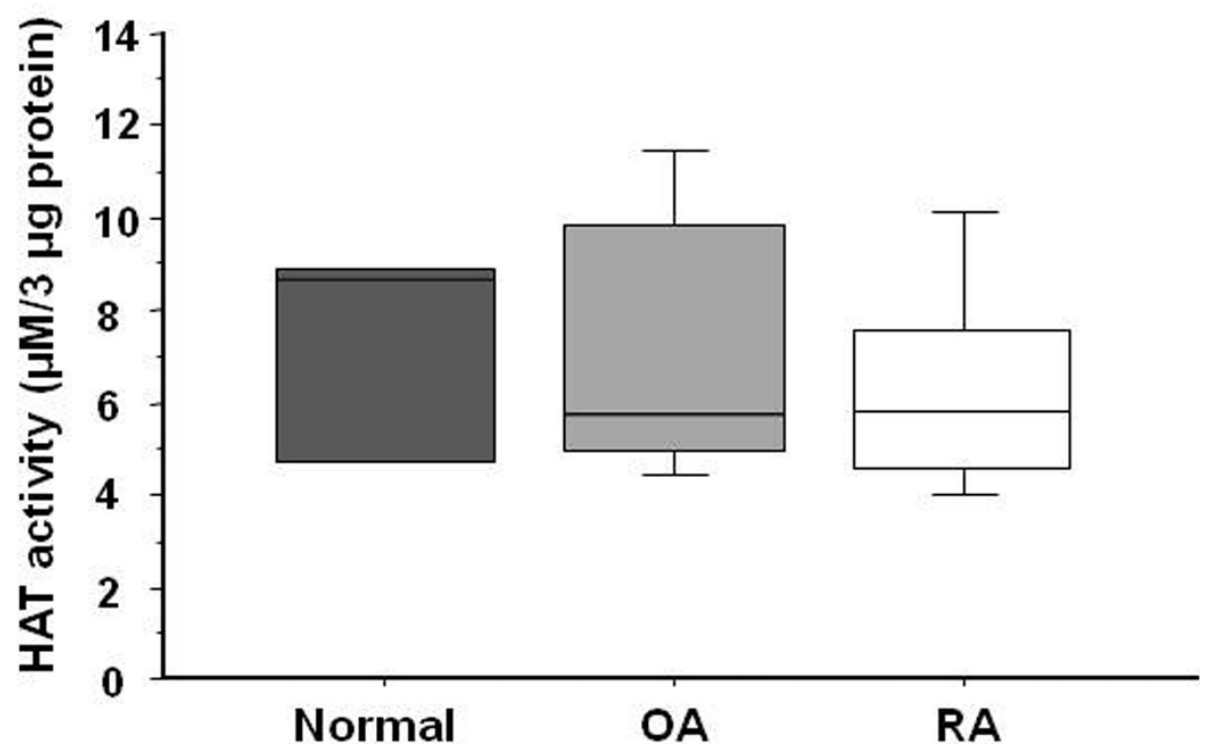

Figure 1 Total nuclear histone deacetylase (HDAC) and histone deacetylase (HAT) activity in synovial tissues. (a) Nuclear HDAC activity in synovial tissues that were obtained from rheumatoid arthritis (RA, $n=14$ ) patients was significantly increased compared to that from normal controls ( $n$ $=3$ ) and osteoarthritis $(\mathrm{OA}, \mathrm{n}=12$ ). In the box (interquartile range, $\mathrm{IQR}$ ) and whisker (maximum and minimum) plots, the horizontal line inside the box denoted median and the filled circles denote outliers outside IQR $\pm 1.5 \times \mathrm{IQR} .{ }^{*}=P<0.05$ versus normal controls, ${ }^{* *}=P<0.05$ versus $\mathrm{OA}$. (b) Nuclear HAT activity was measured in synovial tissues that were obtained from normal controls $(n=3), O A(n=5)$ and RA patients $(n=5)$. There was no significant difference between normal controls, OA and RA synovial tissues. 


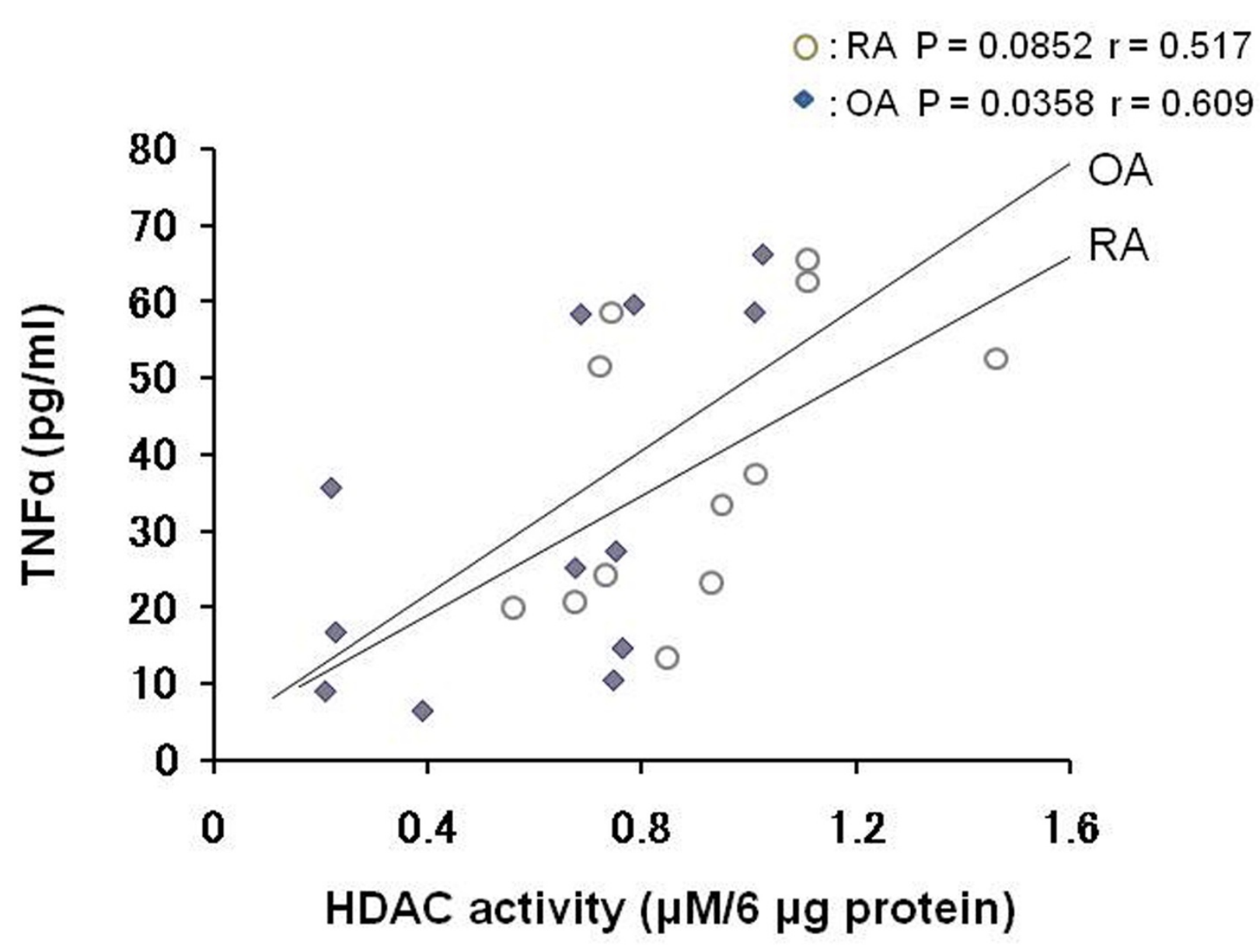

Figure 2 Correlation between the amount of cytoplasmic TNFa and nuclear HDAC activity in synovial tissues. Both cytoplasimc TNFa and nuclear HDAC activity were measured in synovial tissues that were obtained from osteoarthritis $(n=12)$, and rheumatoid arthritis $(n=12)$ patients. The cytoplasmic fraction was obtained during the isolation of the nuclear fraction, and analyzed by ELISA.

resulted partly from the difference in the number of samples.

In chronic inflammation diseases, such as RA, TNF $\alpha$ is a master cytokine that governs the disease process by inducing a variety of inflammatory mediators through activation of the transcription factor, NF- $\mathrm{kB}$, and the MAP kinase cascade. We examined the relationship between nuclear HDAC activity and cytoplasmic TNF $\alpha$ in synovial tissue (Figure 2). They were significantly correlated in OA synovial tissue, whereas they did not reach statistically significant correlation in RA synovial tissues $(\mathrm{r}=0.517, P=0.0852)$. These data imply a limitation of the current study that nuclear HDAC activity and cytoplasmic TNFa levels in synovial tissues from RA patients can be affected by medical treatments with DMARDs or corticosteroid.

The previous study reported that TNF $\alpha$ modestly activated HDAC activity in airway smooth muscle cells [34]. Our in vitro study indicated that stimulation by TNF $\alpha$ up-regulated HDAC activity in RASFs, suggesting the downstream role of HDAC in exacerbation of the inflammation, and that the inhibition of HDAC activity results in the suppression of arthritis. Therefore, blockage of TNF by biologic agents might result in the inhibition of HDAC activation in synovial tissue.

On the other hand, anti-inflammatory effects shown by inhibition of HDAC activity $[15,19]$ might be associated with the inhibition of the TNF $\alpha$-induced NF- $\mathrm{kB}$ pathway. In non-small cell lung cancer (NSCLC), the HDAC inhibitor superoylanilide hydroxamic acid (SAHA) displayed antitumor efficacy by delayed IкB- $\alpha$ phosphorylation [35]. Butyrate, a classical HDAC inhibitor, inhibited NF$\kappa B$ DNA binding within 30 minutes of TNF $\alpha$ stimulation, consistent with the inhibition of NF- $\mathrm{kB}$ nuclear translocation in colonocytes [36]. The influence of HDAC inhibitors on transcriptional co-factors or/and co-activators after DNA binding of NF- $\mathrm{kB}$ still requires further investigation in RA. 


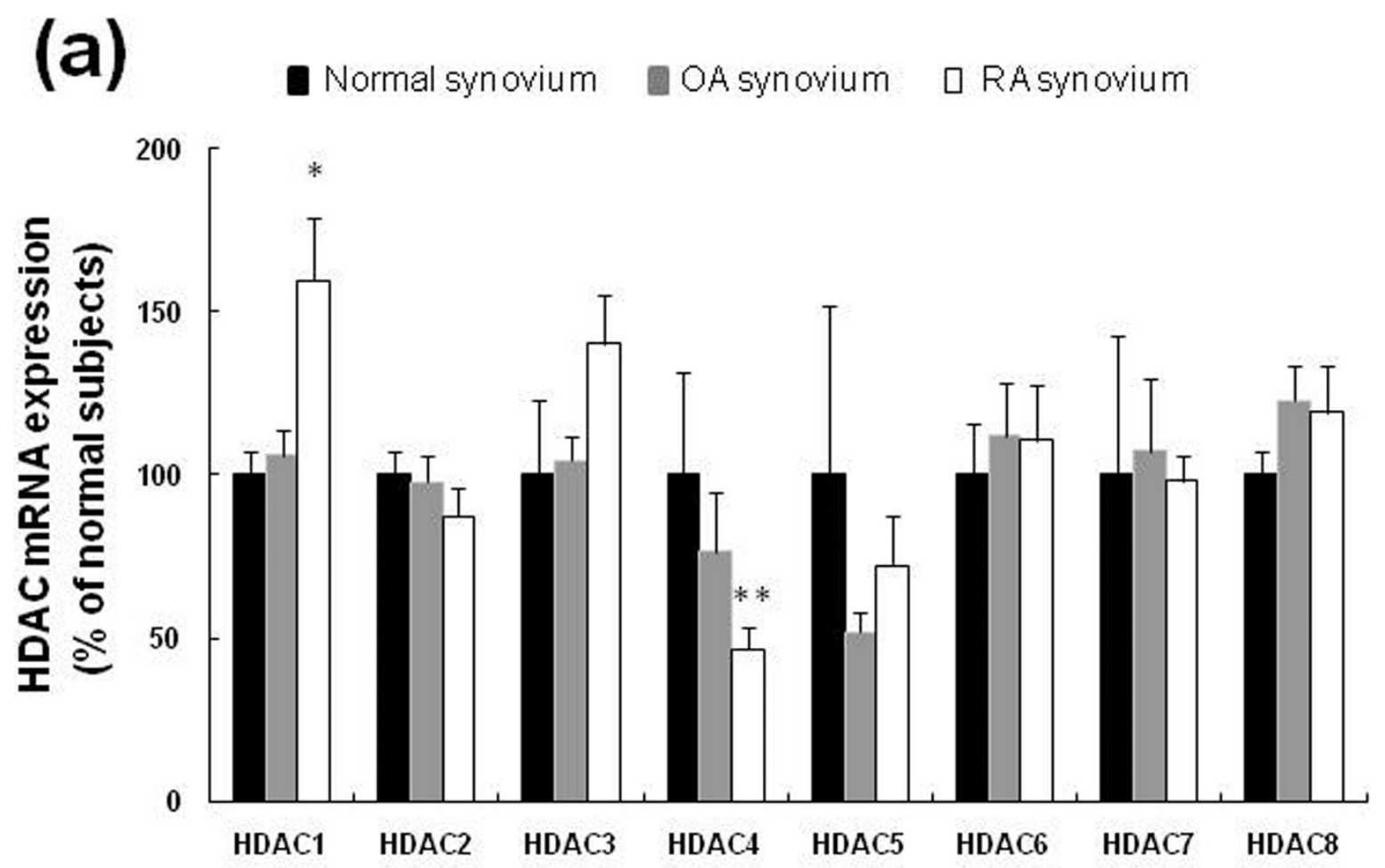

(b)

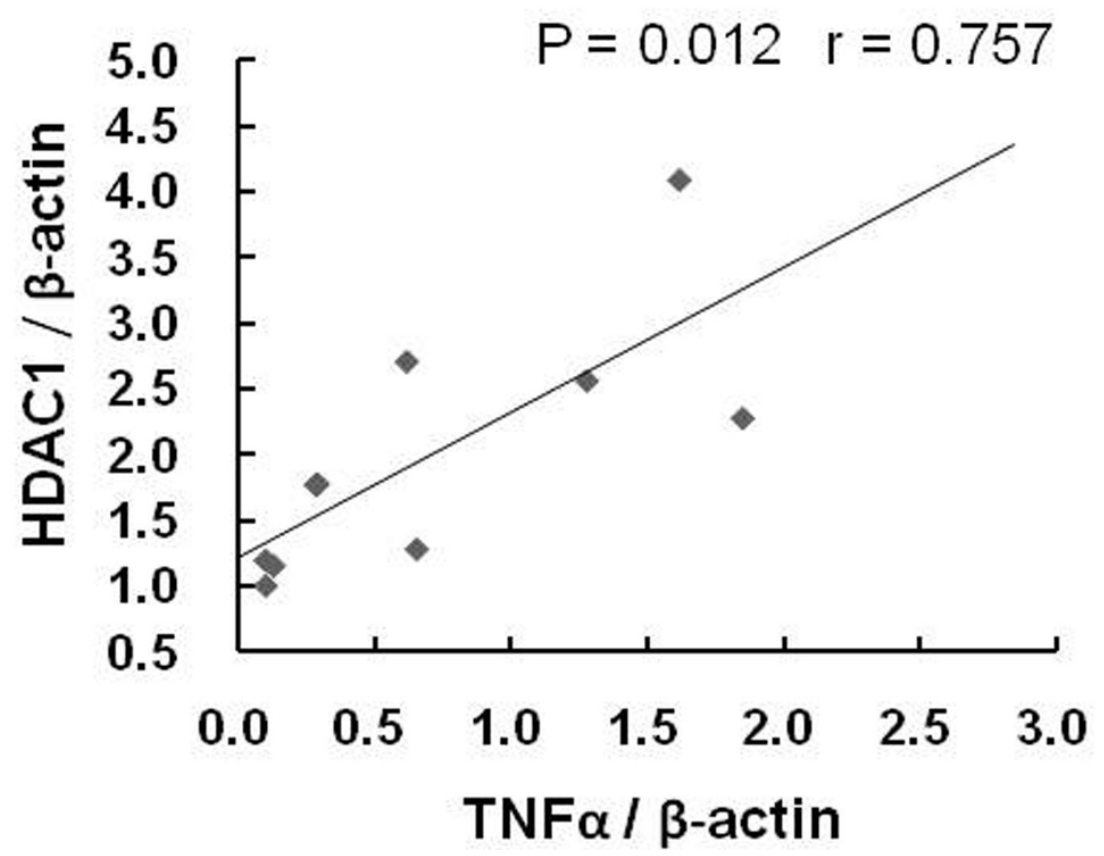

Figure 3 HDAC1-8 mRNA expression and correlation between TNFa mRNA and HDAC1 mRNA expressions in synovial tissues. Total RNA was extracted from total synovial tissues that were obtained from normal controls $(n=3)$, osteoarthritis $(O A, n=8)$ and rheumatoid arthritis $(R A, n=9)$ patients. (a) HDAC1-8 mRNA expression was analyzed by quantitative real-time PCR analysis as described in Materials and Methods. ${ }^{*}=P<0.05$ versus $\mathrm{OA}^{* *}=P<0.05$ versus normal controls. (b) Correlation between TNFa mRNA expression and HDAC1 mRNA in RA synovial tissues $(n=10)$. 
(a)

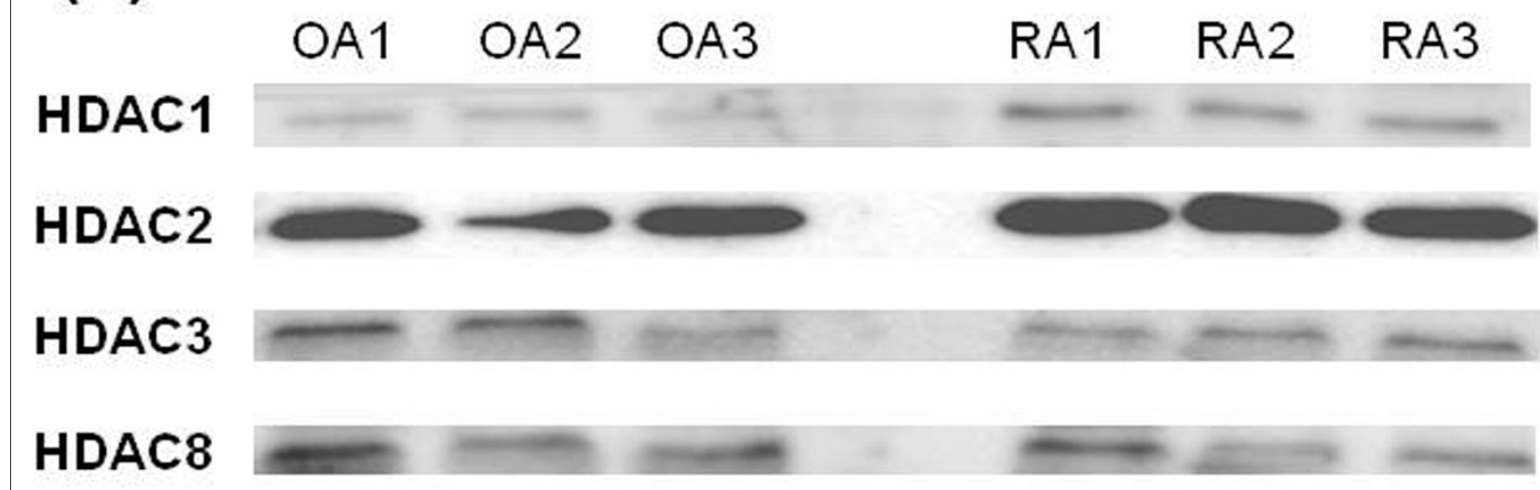

\section{HDAC2}

\section{Lamin A}

\section{(b)}

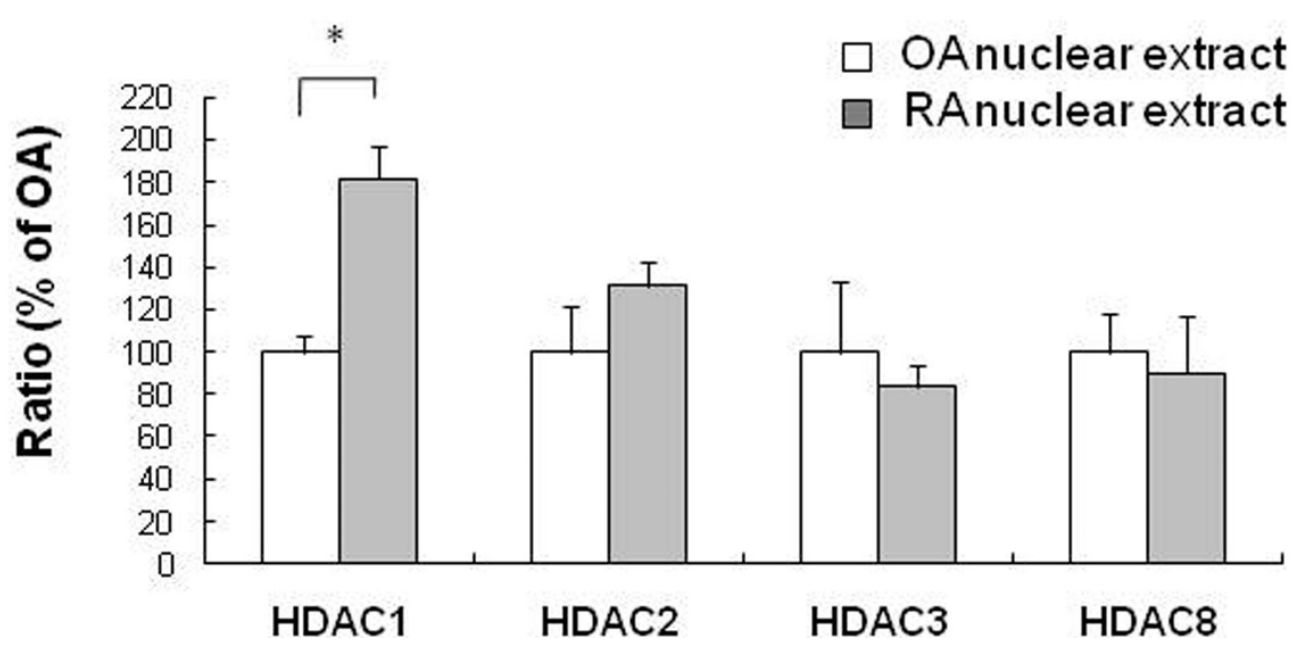

Figure 4 Results of Western blot analysis for nuclear class I HDACs protein expressions in synovial tissues. (a) Class I HDACs (HDAC1, 2, 3, 8) protein expressions in synovial tissues that were obtained from osteoarthritis $(\mathrm{OA}, \mathrm{n}=3)$ and rheumatoid arthritis $(\mathrm{RA}, \mathrm{n}=3)$ synovial tissues. Lamin $\mathrm{A}$, nuclear membrane protein, served as loading control. (b) Densitometric analysis class I HDACs protein in OA and RA synovial tissue was The data were plotted as means \pm SE. ${ }^{*}=P<0.05$ versus $\mathrm{OA}$.

Next, we attempted to investigate HDAC specificity in RA inflammation. In RA synovial tissues, we demonstrated that HDAC1 was specifically up-regulated in mRNA expression and protein levels. Western blot analysis of class I HDACs in synovial tissues showed that the expression of HDAC1 protein was significantly increased in RA lesions, compared with OA lesions. In RASFs, only HDAC1 mRNA and HDAC1 protein expression among class I HDACs increased through the time courses after
TNF $\alpha$ stimulation, suggesting that HDAC1 overexpression might be associated with the enhanced inflammatory reaction. A previous report showed the effects of therapeutic administration of the HDAC inhibitor, SAHA and MS-275 on disease progression and joint destruction in collagen-induced arthritis in rat and mouse models [22]. Although SAHA exhibited moderate prophylactic efficacy, but could not inhibit the onset of arthritis, MS275 displayed dramatic anti-rheumatic activities. In pro- 

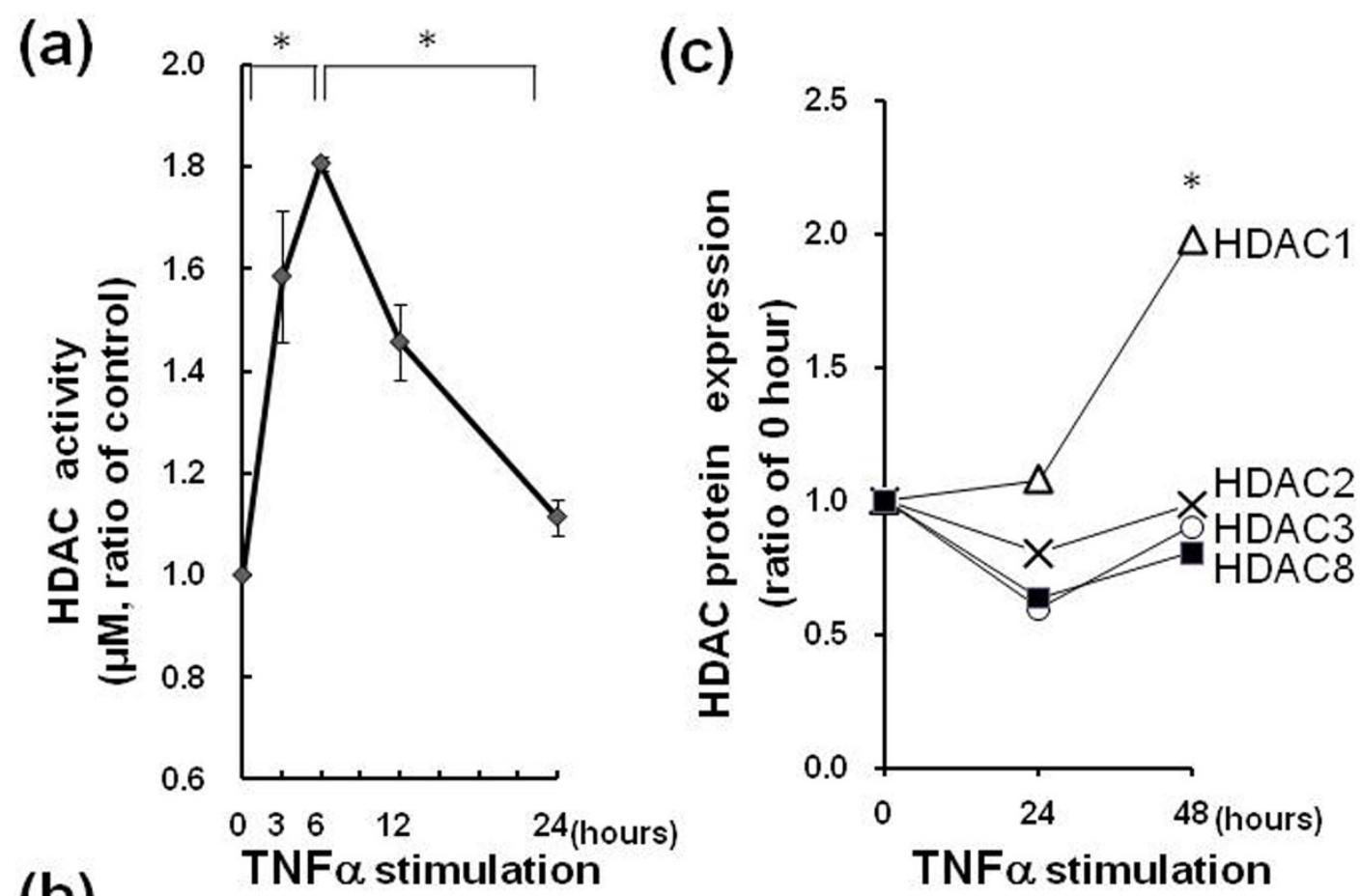

(b)

TNF $\alpha$ stimulation

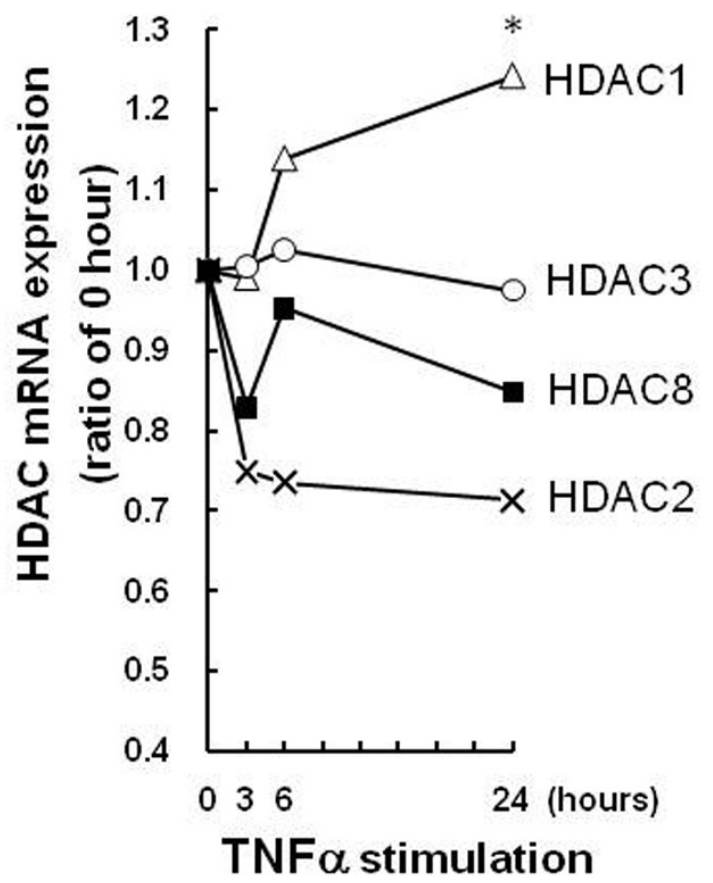

Figure 5 Nuclear HDAC activity, class I HDACs mRNA and protein expressions in RASFs after TNFa treatment. RASFs $(n=3)$ were treated with TNFa $(10 \mathrm{ng} / \mathrm{ml})$ and total nuclear protein was extracted at the indicated time points. (a) Nuclear HDAC activity was elevated significantly at $6 \mathrm{~h}$. The data were plotted as means \pm SE. ${ }^{*}=P<0.001$ versus time $0 \mathrm{~h}, 24 \mathrm{~h}$. (b) The expression of HDAC1 in RASFs was increased after TNFa treatment, while the expressions of other class I HDACs were not elevated. The increase of mRNA in HDAC1 at $24 \mathrm{~h}$ was significantly greater than that in other class I HDACs. For real-time PCR analysis, levels of mRNA were normalized against $\tilde{\beta}$ actin expression and compared with $0 \mathrm{~h} .{ }^{*}=P<0.05$ versus HDAC2, 3, 8. (c) Quantitative results of Western blot analysis of nuclear class I HDACs protein expression in RASFs. The band intensity of class I HDACs was measured by Image J software. For analysis, levels of protein expression were normalized by lamin A and compared with $0 \mathrm{~h} .{ }^{*}=P<0.05$ versus HDAC3 and HDAC8 at $48 \mathrm{~h}$. 
phylactic intervention, high doses of MS-275 prevented bone erosion, and displayed dramatic anti-rheumatic activities. The authors concluded that the superior antiinflammatory effects of MS-275 might be due to its specificity towards class I HDACs, especially HDAC1.

The disruption of both HDAC1 alleles results in embryonic lethality, as a result of severe proliferation defects and retardation in development [37]. Published data indicate that HDAC1 knockdown by siRNA induces a mitotic defect, cell growth inhibition, and an increased percentage of apoptotic cells in human tumor cells [38]. These findings indicate that HDAC1 has important roles in development and proliferative disease, which may include tumor-like proliferative inflammatory disease, such as RA. HDAC1 target genes include Bax, cytokeratin 18, p21 WAF1/Cip1, p27KIP1, p16 ${ }^{\text {INK4a }}$ and p53 [18,37,39-41]. Especially, several studies suggest that the tumor suppressor gene p53 is a key regulator in rheumatoid inflammation. p53 mutations in RA synovial tissue and RASF have been reported, although there is some variability in the number of mutations identified [42,43]. Loss of p53 function in RASF and in collagen antibody-induced mice enhances proliferation, cartilage invasion and anchorageindependent growth while suppressing apoptosis, thereby recapitulating the rheumatoid phenotype $[38,44]$. It is known that HDAC1 deacetylates p53 in vitro and in vivo, and down-regulates p53 transcriptional activity [45,46]. Effective degradation of $\mathrm{p} 53$ is mediated by the ubiquitin ligase Mdm2, as well as in RA [47], and Mdm2 can promote p53 deacetylation by recruiting a complex containing HDAC1 [48]. Most recently, Horiuchi et al. also showed HDAC1 is overexpressed in RASF compared to OA synovial fibroblasts [41]. Knockdown of HDAC1 and HDAC2 by siRNA resulted in increased expression of p16, p21, and p53, and decreased cell counts and cell proliferation, and increased apoptosis in RASF. These data cumulatively support the idea that HDAC1 might be involved in RA pathogenesis by regulating the cell cycle of synovial tissue, and might contribute synovial inflammation.

\section{Conclusions}

The relationship between histone acetylation and RA pathogenesis has not been elucidated. Our results indicate that higher HDAC activity might be linked with higher amounts of cytoplasmic TNFo in RA synovial tissues. Among HDACs, increased activity and expression of nuclear HDAC1 in synovial cells might play a role in RA inflammation.

\section{Additional material}

Additional file 1 Results of Western blot analysis for nuclear class I HDACs protein expressions in synovial tissues. Nuclear class I HDACs ( $H D A C 1,2,3,8)$ protein expressions were obtained from synovial tissues of $\operatorname{RA}(n=1)$ and $O A(n=1)[29]$.
Additional file 2 Results of Western blot analysis for nuclear class I HDACs protein expression in RASFs after TNFa treatment. Nuclear class I HDACs (HDAC1, 2, 3, 8) protein expressions that were obtained from RASFs $(\mathrm{n}=3)$. RASFs were treated with TNFa $(10 \mathrm{ng} / \mathrm{ml})$ at the indicated time points.

\section{Abbreviations}

DMARDs: disease-modifying anti-rheumatic drugs; DMEM: Dulbecco's modified Eagle's medium; FBS: fetal bovine serum; HAT: histone acetyl transferase; HDAC: histone deacetylase; IL: interleukin; MTX: methotrexate; NF: nuclear factor; NSAIDs: nonsteroidal anti-inflammatory drugs; NSCLC: non-small cell lung cancer; OA: osteoarthritis; RA: rheumatoid arthritis; RASF: synovial fibroblasts from rheumatoid arthritis; SAHA: superoylanilide hydroxamic acid; TNF: tumor necrosis factor; TSA: Trichostatin A.

\section{Competing interests}

The authors declare that they have no competing interests.

\section{Authors' contributions}

TK was responsible for the experiments and data analysis and wrote the report. $\mathrm{KN}$ was responsible for the planning of the research and wrote the manuscript. $\mathrm{KT}$ and $\mathrm{HO}$ participated in the design of the study. KS, YK, and Jl assisted with the experiments. SH, YN and HM contributed to the planning of the research. All authors read and approved the final manuscript.

\section{Acknowledgements}

The authors thank Dr T. Furumatsu (Okayama University, Okayama, Japan) for providing clinical samples.

\section{Author Details}

1Department of Medicine and Clinical Science, Okayama University Graduate School of Medicine, Dentistry and Pharmaceutical Sciences, 2-5-1 Shikata-cho, Okayama City, Okayama 700-8558, Japan, 2Department of Human

Morphology, Okayama University Graduate School of Medicine, Dentistry and Pharmaceutical Sciences, 2-5-1 Shikata-cho, Okayama City, Okayama 700-8558, Japan, ${ }^{3}$ Department of Medicine, Kurashiki Kosai Hospital, 5-4-16 Higashiduka, Kurashiki Okayama, 712-8044, Japan, ${ }^{4}$ Department of Molecular Biology and Biochemistry, Okayama University Graduate School of Medicine, Dentistry and Pharmaceutical Sciences, 2-5-1 Shikata-cho, Okayama City, Okayama 700-8558, Japan and 5 Department of Orthopaedic Surgery, Okayama University Graduate School of Medicine, Dentistry and Pharmaceutical Sciences, 2-5-1 Shikata-cho, Okayama City, Okayama 700-8558, Japan

Received: 28 November 2009 Revised: 16 May 2010

Accepted: 7 July 2010 Published: 7 July 2010

\section{References}

1. Mount C, Featherstone J: Rheumatoid arthritis market. Nat Rev Drug Discov 2005, 4:11-12.

2. Huber LC, Stanczyk J, Jungel A, Gay S: Epigenetics in inflammatory rheumatic diseases. Arthritis Rheum 2007, 56:3523-3531.

3. Jenuwein T, Allis CD: Translating the histone code. Science 2001, 293:1074-1080

4. Hassig CA, Schreiber SL: Nuclear histone acetylases and deacetylases and transcriptional regulation: HATs off to HDACs. Curr Opin Chem Biol 1997, 1:300-308

5. Kuo MH, Allis CD: Roles of histone acetyltransferases and deacetylases in gene regulation. Bioessays 1998, 20:615-626.

6. Grozinger CM, Schreiber SL: Deacetylase enzymes: biological functions and the use of small-molecule inhibitors. Chem Bio/ 2002, 9:3-16.

7. Kruh J: Effects of sodium butyrate, a new pharmacological agent, on cells in culture. Mol Cell Biochem 1982, 42:65-82.

8. Chang S, Pikaard CS: Transcript profiling in Arabidopsis reveals complex responses to global inhibition of DNA methylation and histone deacetylation. J Biol Chem 2005, 280:796-804.

9. Mariadason JM, Corner GA, Augenlicht LH: Genetic reprogramming in pathways of colonic cell maturation induced by short chain fatty acids: comparison with trichostatin $\mathrm{A}$, sulindac, and curcumin and implications for chemoprevention of colon cancer. Cancer Res 2000 60:4561-4572

10. Chambers AE, Banerjee S, Chaplin T, Dunne J, Debernardi S, Joel SP, Young BD: Histone acetylation-mediated regulation of genes in leukaemic cells. Eur J Cancer 2003, 39:1165-1175. 
11. Reid G, Metivier R, Lin CY, Denger S, Ibberson D, Ivacevic T, Brand H, Benes V, Liu ET, Gannon F: Multiple mechanisms induce transcriptional silencing of a subset of genes, including oestrogen receptor alpha, in response to deacetylase inhibition by valproic acid and trichostatin A. Oncogene 2005, 24:4894-4907.

12. Huber LC, Brock M, Hemmatazad H, Giger OT, Moritz F, Trenkmann M, Distler JH, Gay RE, Kolling C, Moch H, Michel BA, Gay S, Distler O, Jungel A: Histone deacetylase/acetylase activity in total synovial tissue derived from rheumatoid arthritis and osteoarthritis patients. Arthritis Rheum 2007, 56:1087-1093.

13. Blanchard F, Chipoy C: Histone deacetylase inhibitors: new drugs for the treatment of inflammatory diseases? Drug Discov Today 2005, 10:197-204.

14. Leoni F, Zaliani A, Bertolini G, Porro G, Pagani P, Pozzi P, Dona G, Fossati G, Sozzani S, Azam T, Bufler P, Fantuzzi G, Goncharov I, Kim SH, Pomerantz BJ, Reznikov LL, Siegmund B, Dinarello CA, Mascagni P: The antitumor histone deacetylase inhibitor suberoylanilide hydroxamic acid exhibits antiinflammatory properties via suppression of cytokines. Proc Nat/ Acad Sci USA 2002, 99:2995-3000

15. Chung YL, Lee MY, Wang AJ, Yao LF: A therapeutic strategy uses histone deacetylase inhibitors to modulate the expression of genes involved in the pathogenesis of rheumatoid arthritis. Mol Ther 2003, 8:707-717.

16. Leoni F, Fossati G, Lewis EC, Lee JK, Porro G, Pagani P, Modena D, Moras ML, Pozzi P, Reznikov LL, Siegmund B, Fantuzzi G, Dinarello CA, Mascagni $P$ : The histone deacetylase inhibitor ITF2357 reduces production of pro-inflammatory cytokines in vitro and systemic inflammation in vivo. Mol Med 2005, 11:1-15.

17. Huang N, Katz JP, Martin DR, Wu GD: Inhibition of IL-8 gene expression in Caco-2 cells by compounds which induce histone hyperacetylation. Cytokine 1997, 9:27-36.

18. Bandyopadhyay D, Mishra A, Medrano EE: Overexpression of histone deacetylase 1 confers resistance to sodium butyrate-mediated apoptosis in melanoma cells through a p53-mediated pathway. Cancer Res 2004, 64:7706-7710

19. Nishida K, Komiyama T, Miyazawa S, Shen ZN, Furumatsu T, Doi H, Yoshida A, Yamana J, Yamamura M, Ninomiya Y, Inoue H, Asahara H: Histone deacetylase inhibitor suppression of autoantibody-mediated arthritis in mice via regulation of p16INK4a and p21(WAF1/Cip1) expression. Arthritis Rheum 2004, 50:3365-3376.

20. Sandor V, Bakke S, Robey RW, Kang MH, Blagosklonny MV, Bender J, Brooks R, Piekarz RL, Tucker E, Figg WD, Chan KK, Goldspiel B, Fojo AT, Balcerzak SP, Bates SE: Phase I trial of the histone deacetylase inhibitor, depsipeptide (FR901228, NSC 630176), in patients with refractory neoplasms. Clin Cancer Res 2002, 8:718-728.

21. Ryan QC, Headlee D, Acharya M, Sparreboom A, Trepel JB, Ye J, Figg WD, Hwang K, Chung EJ, Murgo A, Melillo G, Elsayed Y, Monga M, Kalnitskiy M, Zwiebel J, Sausville EA: Phase I and pharmacokinetic study of MS-275, a histone deacetylase inhibitor, in patients with advanced and refractory solid tumors or lymphoma. J Clin Oncol 2005, 23:3912-3922.

22. Lin HS, Hu CY, Chan HY, Liew YY, Huang HP, Lepescheux L, Bastianelli E, Baron R, Rawadi G, Clement-Lacroix P: Anti-rheumatic activities of histone deacetylase (HDAC) inhibitors in vivo in collagen-induced arthritis in rodents. Br J Pharmacol 2007, 150:862-872.

23. Arnett FC, Edworthy SM, Bloch DA, McShane DJ, Fries JF, Cooper NS, Healey LA, Kaplan SR, Liang MH, Luthra HS, et al:: The American Rheumatism Association 1987 revised criteria for the classification of rheumatoid arthritis. Arthritis Rheum 1988, 31:315-324.

24. Morita Y, Yamamura M, Nishida K, Harada S, Okamoto H, Inoue H, Ohmoto $Y$, Modlin RL, Makino H: Expression of interleukin-12 in synovial tissue from patients with rheumatoid arthritis. Arthritis Rheum 1998, 41:306-314

25. Nakamura K, Hirohata S, Murakami T, Miyoshi T, Demircan K, Oohashi T, Ogawa H, Koten K, Toeda K, Kusachi S, Ninomiya Y, Shiratori Y: Dynamic induction of ADAMTS1 gene in the early phase of acute myocardial infarction. J Biochem 2004, 136:439-446.

26. Yamawaki H, Hirohata S, Miyoshi T, Takahashi K, Ogawa H, Shinohata R, Demircan K, Kusachi S, Yamamoto K, Ninomiya Y: Hyaluronan receptors involved in cytokine induction in monocytes. Glycobiology 2009, 19:83-92.

27. Demircan K, Hirohata S, Nishida K, Hatipoglu OF, Oohashi T, Yonezawa T, Apte SS, Ninomiya Y: ADAMTS-9 is synergistically induced by interleukin-1beta and tumor necrosis factor alpha in OUMS-27 chondrosarcoma cells and in human chondrocytes. Arthritis Rheum 2005, 52:1451-1460

28. Hatipoglu OF, Hirohata S, Cilek MZ, Ogawa H, Miyoshi T, Obika M, Demircan K, Shinohata R, Kusachi S, Ninomiya Y: ADAMTS1 is a unique hypoxic early response gene expressed by endothelial cells. J Biol Chem 2009, 284:16325-16333.

29. ImageJ [http://rsb.info.nih.gov/ij/]

30. Luhrs H, Gerke T, Muller JG, Melcher R, Schauber J, Boxberge F, Scheppach W, Menzel T: Butyrate inhibits NF-kappaB activation in lamina propria macrophages of patients with ulcerative colitis. Scand J Gastroenterol 2002, 37:458-466

31. Mishra N, Reilly CM, Brown DR, Ruiz P, Gilkeson GS: Histone deacetylase inhibitors modulate renal disease in the MRL-Ipr/Ipr mouse. J Clin Invest 2003, 111:539-552.

32. Vernia P, Annese V, Bresci G, d'Albasio G, D'Inca R, Giaccari S, Ingrosso M, Mansi C, Riegler G, Valpiani D, Caprilli R: Topical butyrate improves efficacy of 5-ASA in refractory distal ulcerative colitis: results of a multicentre trial. Eur J Clin Invest 2003, 33:244-248

33. Grabiec AM, Tak PP, Reedquist KA: Targeting histone deacetylase activity in rheumatoid arthritis and asthma as prototypes of inflammatory disease: should we keep our HATs on? Arthritis Res Ther 2008, 10:226.

34. Keslacy S, Tliba O, Baidouri H, Amrani Y: Inhibition of tumor necrosis factor-alpha-inducible inflammatory genes by interferon-gamma is associated with altered nuclear factor-kappaB transactivation and enhanced histone deacetylase activity. Mol Pharmacol 2007, 71:609-618

35. Imre G, Gekeler V, Leja A, Beckers T, Boehm M: Histone deacetylase inhibitors suppress the inducibility of nuclear factor-kappaB by tumor necrosis factor-alpha receptor-1 down-regulation. Cancer Res 2006, 66:5409-5418

36. Yin L, Laevsky G, Giardina C: Butyrate suppression of colonocyte NFkappa B activation and cellular proteasome activity. J Biol Chem 2001, 276:44641-44646

37. Lagger G, O'Carroll D, Rembold M, Khier H, Tischler J, Weitzer G, Schuettengruber B, Hauser C, Brunmeir R, Jenuwein T, Seiser C: Essential function of histone deacetylase 1 in proliferation control and CDK inhibitor repression. Embo J 2002, 21:2672-2681.

38. Senese S, Zaragoza K, Minardi S, Muradore I, Ronzoni S, Passafaro A, Bernard L, Draetta GF, Alcalay M, Seiser C, Chiocca S: Role for histone deacetylase 1 in human tumor cell proliferation. Mol Cell Biol 2007, 27:4784-4795

39. Zhou Q, Melkoumian ZK, Lucktong A, Moniwa M, Davie JR, Strobl JS: Rapid induction of histone hyperacetylation and cellular differentiation in human breast tumor cell lines following degradation of histone deacetylase-1. J Biol Chem 2000, 275:35256-35263.

40. Higashitsuji H, Higashitsuji H, Masuda T, Liu Y, Itoh K, Fujita J: Enhanced deacetylation of $\mathrm{p} 53$ by the anti-apoptotic protein $\mathrm{HSCO}$ in association with histone deacetylase 1. J Biol Chem 2007, 282:13716-13725.

41. Horiuchi M, Morinobu A, Chin T, Sakai Y, Kurosaka M, Kumagai S: Expression and function of histone deacetylases in rheumatoid arthritis synovial fibroblasts. J Rheumatol 2009, 36:1580-1589.

42. Firestein GS, Echeverri F, Yeo M, Zvaifler NJ, Green DR: Somatic mutations in the $\mathrm{p} 53$ tumor suppressor gene in rheumatoid arthritis synovium. Proc Natl Acad Sci USA 1997, 94:10895-10900.

43. Yamanishi Y, Boyle DL, Rosengren S, Green DR, Zvaifler NJ, Firestein GS: Regional analysis of p53 mutations in rheumatoid arthritis synovium. Proc Natl Acad Sci USA 2002, 99:10025-10030.

44. Leech M, Lacey D, Xue JR, Santos L, Hutchinson P, Wolvetang E, David JR Bucala R, Morand EF: Regulation of $\mathrm{p} 53$ by macrophage migration inhibitory factor in inflammatory arthritis. Arthritis Rheum 2003, 48:1881-1889.

45. Kim MM, Yoon SO, Cho YS, Chung AS: Histone deacetylases, HDAC1 and HSIR2, act as a negative regulator of ageing through p53 in human gingival fibroblast. Mech Ageing Dev 2004, 125:351-357.

46. Juan LJ, Shia WJ, Chen MH, Yang WM, Seto E, Lin YS, Wu CW: Histone deacetylases specifically down-regulate p53-dependent gene activation. J Biol Chem 2000, 275:20436-20443

47. Taranto E, Xue JR, Lacey D, Hutchinson P, Smith M, Morand EF, Leech M: Detection of the 553 regulator murine double-minute protein 2 in rheumatoid arthritis. J Rheumato/ 2005, 32:424-429. 
48. Ito A, Kawaguchi Y, Lai CH, Kovacs JJ, Higashimoto Y, Appella E, Yao TP: MDM2-HDAC1-mediated deacetylation of $\mathrm{p} 53$ is required for its degradation. Embo J 2002, 21:6236-6245.

doi: $10.1186 /$ ar3071

Cite this article as: Kawabata et al., Increased activity and expression of histone deacetylase 1 in relation to tumor necrosis factor-alpha in synovial tissue of rheumatoid arthritis Arthritis Research \& Therapy 2010, 12:R133

Submit your next manuscript to BioMed Central and take full advantage of:

- Convenient online submission

- Thorough peer review

- No space constraints or color figure charges

- Immediate publication on acceptance

- Inclusion in PubMed, CAS, Scopus and Google Scholar

- Research which is freely available for redistribution

Submit your manuscript at www.biomedcentral.com/submit 